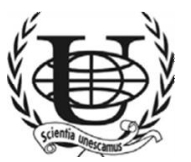

\title{
SOFT LAW REALISATION IN THE CONTEXT OF «PRINCIPLES RELEVANT TO THE USE OF NUCLEAR POWER SOURCES IN OUTER SPACE»: CASE STUDY THE RUSSIAN FEDERATION, THE UNITED STATES OF AMERICA AND THE EUROPEAN UNION STATES
}

\author{
Irina A. Chernykh \\ RUDN University \\ Law Institute \\ 6. Miklukho-Maklaya st., Moscow 117198, Russia
}

Nowadays one of the most significant discussions in the international public law relates to the concept and the role of "soft law". Some researchers assert the point of view of existence of such law, others consider that it is a new source of public international law However, different approaches don't exclude the basic characteristics of soft law that is a non-binding nature and a streamlines process of drafting.

Because of this situation, Member-States of public international organizations tend to use soft law as a pragmatic way of organizing interactions among sovereign states the in case of difficulties to pass unified international treaty. This article argues that similar practices also exist in international space law. Since the entry in force of the Moon Agreement in 1979, the Member States of UN COPUOS have not passed any additional international space treaties. Instead, they have found a solution for new challenges: drafting and accepting soft law acts like UN General Assembly Resolutions (hereinafter GA Resolutions) and others.

While GA Resolutions are not legally binding, States can transform them into national legislations and doing so they will have to be responsible for certain space activities which have not been regulated internationally yet.

The purpose of this article is to provide an overview on the establishment of soft law as a new source of international space law by analyzing and comparing state practice in Russia, the USA and in several Member States of the European Union (EU). The emphasis will be made on the transformation of provisions of the UN General Assembly Resolution "Principles Relevant to the Use of Nuclear Power Sources in Outer Space" (hereinafter the NPS Principles) as nuclear power sources in outer space should be based on a thorough safety assessment.

The article starts by a short overview of the concept of "soft law" and the resolutions produced by UN COPUOS. Then it will go on to the main three parts besides conclusion. The first chapter gives a brief overview of the drafting history of the NPS Principles and the second deals with activities of UN COPUOS and IAEA on the matter of nuclear power sources use in outer space. The last chapter presents several case studies focusing on the following questions which provisions of NPS Principles have been implemented into national legislative system, what is the novel and what are the differences among the various national law instruments in these countries.

Key words: NPS Principles; soft law; space law; UN COPUOS; IAEA; national legislation; Safety Framework for Nuclear Power Source Applications in Outer Space; safety; GA Resolutions 


\section{INTRODUCTION}

This introductory section provides for a brief overview of the "soft law" concept in international space law.

Per se applicability of "soft law" in international public law today is very important. "Soft law documents includes "non-binding principles, norms, standards or other statements of expected behavior in the form of recommendations, charters, terms of reference, guidelines, codes of conduct, etc." (Beard, 2016:5; Marboe, 2012:99-100; Boczek, 2005:477). Also "soft law" is non-binding documents of the UN General Assembly and from the research point of view some scholars recognize it, some of them - not (for instance, there are different points of view on it in European research and in Russian one).

On the one hand, United Nations decisions will be legally binding only for United Nations and its member-States (Tunkin, 2014; Ferdross, 1959). As noted "if the accepted rule of law is treated by the majority of the States (international recognition) and reduced to practice, it will be binding for any States, including not UN MemberStates" (Durdenevskii, Krylov, 1947:24-25; Kozhevnikov, 1957:9).

On the other hand, if the UN GA Resolutions is being adopted by nemine dissentiente or by a two-thirds vote, taking into account representation of the three groups of States, it becomes effective and legally binding for all UN Member-States as such kind of resolution expresses the will of the States represented by States delegations (Tunkin, 2014:144-145), that Kozhevnikov, Morozov and Minasyan draw from their findings (Kozhevnikov, 1959:17; Morozov, 1962:217-218, Minasyan, 1966: 235).

Despite the binding nature of resolutions for the UN Member-States, it will not be sources of international law, but will be part of the standard setting. Although these resolutions/or "soft law" documents can be used as a confirmation of a customary rule of international law or an evidence of the emergence of such rule of law by a court or arbitration tribunal (Vereshchetin, 2010:46).

Some scholars suggest that there is a third category of binding documents, which are sources of international law too - UN GA resolutions, as the distinctions between treaties and resolutions of the international intergovernmental organizations are being eliminated, they say (Schwelb, 1966:25-26; Falk, 1967:487).

French lawyers do not admit "soft law" in view of the fact that it is contravene to the conceptional understanding of law. Russo said that "The law is reasonable only if it represents legally binding obligations" (Portalis, 1820).

"Soft law" documents in comparison with internationally binding treaties don't imply unlawful violation. However, it could be contrary to "best practice" or be accepted as "best practice" enforcement by peer pressure. "Soft law" could be applied both States and private actors and be binding by inclusion in national space law. Whereas treaties are binding only upon States, its violation is unlawful and triggers State responsibility. 
But due to the fact that "soft law" enables to pass documents very fast and without being formally and officially agreed by all states' wishes, it becomes an important and useful legal mechanism at the international level. In addition, "soft law" is flexible and corresponds to the obligatory rules of law. It is also very effective through peer pressure, inclusion in national space legislation, tool for an interpretation and application of existing space law treaties and other obligations, tool for a setting different standards, guidelines or regulations, which create obligations of a procedural nature; it can lead to harmonized international procedural standards that in turn may generate legally binding domestic legislation and regulations; it may later form the basis of legally binding international agreements or crystallize into rules of customary international law (Beard, 2016; Marboe, 2012).

However, it is also disputed whether "soft law" is efficient and effective enough for some of today's most urgent challenges, e.g. use of nuclear power sources, space debris or space safety. Vague, imprecise, ambiguous or otherwise indeterminate language makes it easier for states to justify noncompliance of any documents. But some researchers have suggested that "soft law has emerged as the "most appropriate tool" for ensuring the security of space objects and preventing an arms race in space" (Marboe, 2012:361, 372). Still and all what does it mean for international space law?

Celebrating this year anniversary of the Treaty on Principles Governing the Activities of States in the Exploration and Use of Outer Space, including the Moon and Other Celestial Bodies ${ }^{1}$ (OST), we can reasonably say today that international space law is continuously developing. In the same time, today the world community can't expect drafting new "hard law" document or reviewing five international space law treaties (bearing in mind that four of them partially run past provisions of OST, that isn't good for rule-making). Otherwise by contrast with international space law in the different branches of international public law such as international air law or international law of the sea, we can't find so many resolutions. Thus, soft law is essential element and characteristic of this branch of law - international space law.

It indicates that such kind of mechanism as soft law allow (Dunk, 2012): 1) being applied by states in complex with space treaties provisions on the governmental level through transformation or other legal instruments; 2) to fill the gaps in the existing law; 3) to regulate developing space technologies, which could be innovate for the world and for international public law; 4) to ensure long-term sustainability of outer space activities in the context of its safety. There is different scope of application soft law documents: political (UN GA Resolutions), technical (NPS Safety Framework) or legal (UN GA Resolutions - Concept of launching state).

\footnotetext{
${ }^{1}$ Treaty on Principles Governing the Activities of States in the Exploration and Use of Outer Space, Including the Moon and Other Celestial Bodies, 610 U.N.T.S. 205 (entered into force October 10, 1967). Available from: http://www.unoosa.org/pdf/gares/ARES_21_2222E.pdf [Accessed 28th February 2017].
} 
Nowadays we have following examples of General Assembly resolutions drafting by UNCOPUOS:

- RES 1721 (XVI) International Co-operation in the Peaceful Uses of Outer Space $1961^{2}$ (General Assembly 16th session - adopts every year on the questions of the activities to be undertaken within the Programme on Space Applications of the Office for Outer Space Affairs;

- RES 1962 (XVIII) Declaration of Legal Principles Governing the Activities of States in the Exploration and Use of Outer Space (General Assembly 18th session) ${ }^{3}$;

- RES 37/92 Principles Governing the Use by States of Artificial Earth Satellites for International Direct Television Broadcasting (General Assembly $37^{\text {th }}$ session) ${ }^{4}$;

- RES 41/65 Principles relating to remote sensing of the Earth from outer space ${ }^{5}$ (General Assembly $41^{\text {st }}$ session);

- RES 47/68 Principles Relevant to the Use of Nuclear Power Sources in Outer $\operatorname{Space}^{6}$ (General Assembly $47^{\text {th }}$ session);

- A/RES/51/122 Declaration on International Cooperation in the Exploration and Use of Outer Space for the Benefit and in the Interest of All States, Taking into Particular Account the Needs of Developing Countries ${ }^{7}$ (General Assembly $51^{\text {st }}$ session);

- A/RES/59/115 Application of the concept of the «launching State» ${ }^{8}$ (General Assembly $59^{\text {th }}$ session);

- A/RES/62/101 Recommendations on enhancing the practice of States and international intergovernmental organizations in registering space objects ${ }^{9}$ (General Assembly $62^{\text {nd }}$ session);

$-\mathrm{A} / \mathrm{RES} / 62 / 217$ International cooperation in the peaceful uses of outer space ${ }^{10}$ (General Assembly $62^{\text {nd }}$ session) - the resolution endorsing the Space Debris Mitigation Guidelines;

\footnotetext{
2 RES 1721 (XVI) International Co-operation in the Peaceful Uses of Outer Space 1961 (December 20, 1961). Available from: http://www.unoosa.org/pdf/gares/ARES_16_1721E.pdf [Accessed 28th February 2017].

${ }^{3}$ The Declaration of Legal Principles Governing the Activities of States in the Exploration and Use of Outer Space. UN General Assembly Resolution 1962 (XVIII) of 13 December 1963. Available from: http://www.unoosa.org/pdf/gares/ARES_18_1962E.pdf [Accessed 28th February 2017].

4 Adopted by the General Assembly in its Resolution 37/92 of 10 December 1982. Available from: http://www.unoosa.org/pdf/gares/ARES_37_92E.pdf [Accessed 28th February 2017].

5 Adopted by the General Assembly in its Resolution 41/65 of 3 December 1986. Available from: http://www.unoosa.org/pdf/gares/ARES_41_65E.pdf [Accessed 28th February 2017].

6 Adopted by the General Assembly in its Resolution 47/68 of 14 December 1992. Available from: http://www.unoosa.org/pdf/gares/ARES_47_68E.pdf [Accessed 28th February 2017].

7 Adopted by the General Assembly in its Resolution 51/122 of 4 February 1997. Available from: http://www.unoosa.org/pdf/gares/ARES_51_122E.pdf [Accessed 28th February 2017].

8 Adopted by the General Assembly in its Resolution 59/115 of 25 January 2005. Available from: http://www.unoosa.org/pdf/gares/ARES_59_115E.pdf [Accessed 28th February 2017].

9 Adopted by the General Assembly in its Resolution 62/101 of 10 January 2008. Available from: http://www.unoosa.org/pdf/gares/ARES_62_101E.pdf [Accessed 28th February 2017].
} 
- A/RES/68/74 Recommendations on national legislation relevant to the peaceful exploration and use of outer space ${ }^{11}$ (General Assembly 68th session) and etc ${ }^{12}$.

Next year it's expected that Resolution with set of guidelines for the long-term sustainability of outer space activities ${ }^{13}$ also will be adopted.

\section{GENESIS OF NPS PRINCIPLES}

As pointed out earlier in this paper, this chapter is dedicated to the NPS Principles. It contains such provisions which should be ensured safety for the world and be suggested adequate base for operations in space. Whereas GA Resolutions don't have a binding force, states may transform its provisions to the national legislations and thus have to be responsible for the certain space activities which aren't regulated internationally.

NPS Principles have been produced for more than 20 years in UN COPUOS in Scientific and Technical Subcommittee (hereinafter STSC) together with Legal Subcommittee (hereinafter LSC). The use of nuclear power sources was already discussed in LSC on Liability Convention's aspects such as problems of responsibility, liability and compensation. This situation was due to the numerous fault launchings and operations cases: Transit-5BN-3 (21.04.1964), Nimbus-B-1 (18.05.1968), Rorsat (25.01.1968; 25.04.1973), Cosmos-1402 (07.02.1983), Appolo-13 with the nuclear generator (SNAP-27) etc., but especially Cosmos-954 (24.01.1978). These satellites used to operate on fission reactors ${ }^{14}$ (Aftergood et al., 1991:42-47) or radioisotope thermoelectric generators $\left(\mathrm{RTGs}^{15}\right.$ ) and radioisotope heater units (RHU) ${ }^{16}$. RTGs and RHUs are also named as radioactive power sources (RPS). RHUs are used in the engineering for a protection of satellite instruments from the cold in outer space. It also operates on Pu-238 fuel. "The main concern in the use of RTGs in spacecraft is contamination due to a launch failure or failure during operations in earth orbit ${ }^{17}$."

10 Adopted by the General Assembly in its Resolution 62/217 of 1 February 2008. Available from: http://www.unoosa.org/pdf/gares/ARES_62_217E.pdf [Accessed 28th February 2017].

11 Adopted by the General Assembly in its Resolution 68/74 16 December 2013. Available from: http://www.unoosa.org/pdf/gares/A_RES_68_074E.pdf [Accessed 28th February 2017].

${ }^{12}$ See: Documents and resolutions database at official site of The United Nations Office for Outer Space Affairs (UNOOSA). Available from: http://www.unoosa.org/oosa/documents-and-resolutions/search.jspx? \&view=resolutions [Accessed 28th February 2017].

${ }^{13}$ Adopted by the Committee on the Peaceful Uses of Outer Space in its Document A/AC.105/L.301 of 5 December 2016. Available from: http://www.unoosa.org/res/oosadoc/data/documents/2016/aac_1051/ aac_1051_301_0_html/AC105_L301E.pdf [Accessed 28th February 2017].

${ }^{14}$ It works on Uranium-235; it is "small fission reactors that are in principle similar to terrestrial reactors but with different retained design options, especially for reactors cores, cooling, moderation and control system".

${ }^{15}$ RTGs work on Pu-238.

${ }^{16}$ Safety Framework for Nuclear Power Source Applications in Outer Space. International Atomic Energy Agency, Vienna, 2009. Available from: https://fas.org/nuke/space/iaea-space.pdf [Accessed 28th February 2017].

${ }^{17}$ Report of the Scientific and Technical Subcommittee of the Committee on the Peaceful Uses of Outer Space. COPUOS 54 ${ }^{\text {th }}$ Session, U.N. Doc. A/AC.105/C.1/2017/CRP.12. (January 31, 2017). 
Nevertheless, the NPS Principles seek to protect the Earth and outer space environments from damage caused by the use of NPS in spacecraft (Aftergood, 1989:93107). But NPS Principles is applicable only to RTGs and RHUs sources, and not to nuclear propulsion.

\section{ACTIVITY OF UN COPUOS AND IAEA}

Complementary to the existing NPS Principles in 2009 STSC in the framework of the Working Group on the Use of Nuclear Power Sources in Outer Space in cooperation with IAEA, the Safety Framework for Nuclear Power Source Applications in Outer Space ${ }^{18}$ was also adopted in 2009 , which will allow to promote the safety of NPS applications in outer space and be utilized as a guide for the national purposes. The working Group on the Use of Nuclear Power Sources in Outer Space (STSC), which has a long record of productive work on these matters under its consideration, is currently working on a regular basis part of the multi-year work plan objectives. For instance, on its $54^{\text {th }}$ Session was accepted a new work-plan for the period 2017 $2021^{19}$. The main objectives for this period became:

- The promotion and facilitation on the implementation of the Safety Framework;

- The discussion advances in knowledge and practices and their potential for enhancing the technical content and scope of the Principles Relevant to the Use of $\mathrm{Nu}$ clear Power Sources in Outer Space [through presentations from member States and international intergovernmental organizations].

The Working Group on the Use of Nuclear Power Sources in Outer Space has recently accepted its new work-plan for the next 5 years and which is based on as the following activities: a) holding teleconferences and meetings; b) making and receiving technical presentations by States members of the Committee; c) identifying any significant challenges; d) preparation a draft report summarizing the technical presentations.

It is important to underline at this stage that mostly of the activities of the Working Group deals with challenges faced by States and intergovernmental organizations to enhance safety in the development and use of space NPS applications, due to this fact we should remember that according to the first principle of the NPS Principles, its provisions are addressed to all states ${ }^{20}$.

\footnotetext{
${ }^{18}$ Safety Framework for Nuclear Power Source Applications in Outer Space 2009, Committee on the Peaceful Uses of Outer Space and International Atomic Energy Agency. U.N. Doc. A/AC.105/934 (May 19, 2009).

${ }^{19}$ Report of the Scientific and Technical Subcommittee on its fifty-fourth session, held in Vienna from 30 January to 10 February 2017 U.N. Doc. A/AC.105/1138*. (February 21, 2017). Available from: file://C:/Users/user/Desktop/V1701120.pdf [Accessed 10th May 2017].

20 Adopted by the General Assembly in its Resolution 47/68 of 14 December 1992. Available from: http://www.unoosa.org/pdf/gares/ARES_47_68E.pdf [Accessed 28th February 2017]. Principle 1.
} 
This issue reveals the need to further investigate this situation in greater details with brief case study of some states specifically Russia, the EU and the USA.

National space legislations that are currently applicable contain different norms focusing on environmental protection and safety of space operations, including missions depended on nuclear power sources.

\section{CASE STUDY}

\subsection{United States of America}

We can find in the history of the US launchings several failures of operation systems involving nuclear power sources ${ }^{21}$. To avoid additional failures, the legislator has imposed a double requirements (redundant) system for the use of nuclear power sources. Firstly, the US National Environmental Policy Act 1969 (NEPA) imposes complex technical regulations ${ }^{22}$. Secondly, US agencies (NASA, Department of Energy, Department of Defense) have established specific safety internal procedure and audits named as Nuclear Launch Safety Approval (hereinafter NLSA).

The stated purposes of NEPA mentioned above are as follows:

- to declare a national policy which will encourage productive and enjoyable harmony between man and his environment;

- to promote efforts which will prevent or eliminate damage to the environment and biosphere and stimulate the health and welfare of man;

- to enrich the understanding of the ecological systems and natural resources important to the Nation, and;

- to establish a Council on Environmental Quality ${ }^{23}$.

For overseeing NEPA regulations was established the President's Council on Environmental Quality (hereinafter CEQ) ${ }^{24}$. In 1978, the President's Council on Environmental Quality issued regulations to implement NEPA ${ }^{25}$. These regulations are binding upon all federal agencies. However, additional regulations and mandatory procedures may vary from agency to agency as they are specific to each mission and related activities of the agency. NASA has such kind of specific regulation - Procedures for Implementing the National Environmental Policy $\mathrm{Act}^{26}$.

\footnotetext{
${ }^{21}$ Radio-isotope power systems working to meet the energy needs 21 space objects since 1961 to 1979: three were abortive (launch and ending up in the depths of the South Pacific, burning up on re-entry, at launch and recovered from the Atlantic Ocean).

${ }^{22}$ US National Environmental Policy Act was signed into law on January 1, 1970. Pub. L. No. 91-190, 83 Stat. 852 (January 1, 1970).

${ }_{23}^{23}$ National Environmental Policy Act of 1969. Sec. 242 USC § 4321.

${ }^{24}$ Ibid. Title II.

${ }^{25}$ Regulations for Implementing the Procedural Provisions of the National Environmental Policy Act, 40 CFR Parts 1500-1508, 70 FR 41148 (July 18, 2005). Available from: https://energy.gov/sites/prod/files/NEPA40CFR1500_1508.pdf [Accessed 10th March 2017].

${ }^{26}$ Procedures for Implementing the National Environmental Policy Act, CFR-2012 (Revised as of October 1, 2012). Title 14, vol. 5, part 1216, subpart 1216-3, § 1216.302 .
} 
The Act imposes that a NASA action shall require the preparation of an environmental assessment provided the action is not one normally requiring an environmental impact statement or it is not categorically excluded from the requirement for an environmental assessment and an environmental impact ${ }^{27}$.

In addition to the CEQ NEPA regulations, CEQ has issued a several guidance documents on the implementation of NEPA. Many federal agencies have also developed their own NEPA procedures supplementing the CEQ NEPA regulations.

There are two types of procedures: preparation of the environmental assessment (hereinafter EA) and preparation of the Environmental Impact Statement (hereinafter EIS) subject to public review and comment by the responsible official, which are carried out depending on the situation.

Preparation of an environmental assessment EA by NASA is carried out in the cases:

- Specific spacecraft development and flight projects in space science; plications;

- Specific spacecraft development and flight projects in space and terrestrial ap-

- Specific experimental projects in aeronautics and space technology and energy technology applications;

- Development and operation of new space transportation systems and advanced development of new space transportation and spacecraft systems;

- Reimbursable launches of non-NASA spacecraft or payloads;

- Major Construction of Facilities projects;

- Actions to alter ongoing operations at a NASA installation which could lead, either directly or indirectly, to natural or physical environmental effects.

Preparation of EIS for public review and comment by the responsible official, all in the R\&D budget category, is applicable in the following situations:

1) development and operation of new launch vehicles;

2) development and operation of space vehicles likely to release substantial amounts of foreign materials into the earth's atmosphere, or into space;

3 ) development and operation of nuclear systems, including reactors and thermal devices used for propulsion and/or power generation (excluded are devices with millicurie quantities or less of radioactive materials used as instrument detectors and small radioisotope heaters used for local thermal control, provided they are properly contained and shielded).

Even though an action may be categorically excluded from the need for a formal environmental assessment or environmental impact statement, it is not excluded from the requirement for an environmental analysis to be conducted during the earliest planning phases.

${ }^{27}$ Ibid. § 1216.305 "Criteria for actions requiring environmental assessments”. 
In the framework of the NLSA process shall be provided:

- The Nuclear Safety Analysis Report; Panel;

- A Safety Evaluation Report by ad hoc Inter-agency Nuclear Safety Review

- Approval from the White House by the Director of the Office of Science and Technology Policy or by President;

- Drafting multi-agency radiological contingency plan by NASA and Department of Energy.

As was mentioned before, that public opinion in the USA has a significant role for ecological protection leading sometimes to judicial proceedings when NASA had failed to comply with the requirements of this NEPA Act. For an example, see Florida Coalition for peace and Justice v. George Herbert Walker Bush (Bennett, Sholtis, Rashkow, 1989:45-58; Bennet, 1995).

\subsection{The Russian Federation}

The powered satellite Cosmos 954 that crashed on Canadian territory in 1977 led to the adoption of several legal instruments by the USSR (Russia). Following the crash, the Russian Federation implemented a system based on responsible bodies and federal legislation. The main national space law document is Decree 5663-1 "About Space Activity" 28 which stipulates that "space activity is carried out on the base of principles safety of space activity, including protection of the environment as well as access to information about space activity" 29 . Decree states a licensing of space activity $^{30}$ and a certification of space technology ${ }^{31}$. The whole Section V, consisting of 4 articles, of the Decree is devoted to the safety of space activity. Federal executive body on space activity and federal executive body on defense are responsible for ensuring security. However, this act includes general provisions. The most important document on the use of nuclear power sources in outer space in the context of safety is Federal Act "On Use of Nuclear Energy" ${ }^{32}$. The Chapter 43 imposes special requirements on spacecraft and aircraft using nuclear facilities and/or radiation sources $^{33}$. Provisions are similar to the general norms on the environmental defense: ecological requirements, obligation of mutual assistance and compatibility of national law with international law.

Before the launching in the case of emergency federal executive bodies, for instance, the Russian Federal Atomic Energy Agency (ROSATOM), governed by the Rules for Notifying the Executive Authorities and the Governmental Order № 1039

\footnotetext{
${ }^{28}$ The Space Activities Act of 20 July 1993. The Russian Gazette of 06 October 1993.

${ }^{29}$ Ibid., art. 4 "The Principles of Space Activity".

${ }^{30}$ Ibid., art. 9 "Licensing of Space Activity".

${ }^{31}$ Ibid., art. 10 "Certification of Space Technology".

${ }^{32}$ Federal Act No 170 "On Use of Nuclear Energy". Collection of Legislation of Russian Federation of 27 November 1995. No 48. Art. 4552.

${ }^{33}$ Ibid. Chapter 43.
} 
upon launching a spacecraft with a nuclear power source, as well as alerting local governments and providing the assistance to the population if necessary in the event of an emergency return of such a device to the Earth". These rules don't regulate military space crafts but regulate reactors NPS and RTG in the emergency situation of a booster failure at the start or a start false and a failure of the spacecraft in the acceleration from low to high orbit or interplanetary trajectory of the flight. The special kind of such case is a premature acceleration from the high orbits, because of collision with space debris. In such case, the Chairman of the State Commission on the space craft launching is obliged to inform the Ministry of Foreign Affairs which than informs UN Secretary General. Otherwise the Chairman informs the Ministry of the Russian Federation for Affairs for Civil Defense, the Federal Service for Environmental, Technological, and Nuclear Supervision, the Ministry of Defense, the Russian Federal Service for Hydrometeorology and Environmental Monitoring, the Federal Service for Supervision of Natural Resource Usage, Ministry of Health of the Russian Federation. In the case of safety concern, this list is added by Roscosmos and the other executive bodies.

\subsection{European Union}

In the EU there are also mixed system of the legislation on the nuclear powers sources consisting in a combination of EU directives and national legislation adopted by the Member States (Mayence, 2011).

Sources of EU law includes, for instance:

- Council Directive 96/29/EURATOM of 13 May 1996 laying down basic safety standards for the protection of the health of workers and the general public against the dangers arising from ionizing radiation ${ }^{34}$;

- Council Directive 2009/71/EURATOM of 25 June 2009 establishing a Community framework for the nuclear safety of nuclear installations ${ }^{35}$;

- Council Directive 2013/59/EURATOM of 5 December 2013 laying down basic safety standards for protection against the dangers arising from exposure to ionising radiation, and repealing Directives 89/618/Euratom, 90/641/Euratom, 96/29/Euratom, 97/43/Euratom and 2003/122/Euratom ${ }^{36}$;

\footnotetext{
${ }^{34}$ Council Directive 96/29/Euratom of 13 May 1996 laying down basic safety standards for the protection of the health of workers and the general public against the dangers arising from ionizing radiation. Official Journal L 159, P. 0001-0114. Document 31996L0029 (June 29, 1996).

Available from: https://osha.europa.eu/en/legislation/directives/73 [Accessed 10th March 2017].

${ }^{35}$ Council Directive 2009/71/EURATOM of 25 June 2009 establishing a Community framework for the nuclear safety of nuclear installations. Official Journal of the European Union (July 2, 2009). Available from: http:/eurlex.europa.eu/LexUriServ/LexUriServ.do?uri=OJ:L:2009:172:0018:0022:EN:PDF [Accessed 10th March 2017].

${ }^{36}$ Council Directive 2013/59/EURATOM of 5 December 2013 laying down basic safety standards for protection against the dangers arising from exposure to ionising radiation, and repealing Directives 89/618/Euratom, 90/641/Euratom, 96/29/Euratom, 97/43/Euratom and 2003/122/Euratom. Official Journal of the European Union №1, Part II, Non-legislative acts, Directives, L13/1-L13/73, (January 17, 2014) Available from: https://ec.europa.eu/energy/sites/ener/files/documents/CELEX-32013L0059-EN-TXT.pdf [Accessed 10th March 2017].
} 
- Council Decision 87/600/Euratom of 14 December 1987 on Community arrangements for the early exchange of information in the event of a radiological emergency $^{37}$.

National legislations implementing the EU directives and national space law on space activities existing in some countries include for instance:

- Netherlands: Rules Concerning Space Activities and the Establishment of a Registry of Space Objects (Space Activities Act) ${ }^{38}$;

- Austria: Regulation of the Federal Minister for Transport, Innovation and Technology in Implementation of the Federal Law on the Authorisation of Space Activities and the Establishment of a National Space Registry ${ }^{39}$;

- Belgium: Law of 17 September 2005 on the Activities of Launching, Flight Operations or Guidance of Space Objects, consolidated text as revised by the Law of 1 December $2013^{40}$ - Art. $8, \S 9$.

The third block consists of "specialized" documents such as:

- European Code of Conduct for Space Debris Mitigation 28.06.2004 (5.4.1 "Safety policy") — "presents fundamental mitigation and safety measures related to space debris ${ }^{41}$ "... and "is consistent with European space debris policy as presented in document ESA/IRC (2000)14"42.

- CNES Nuclear Safety Requirements $(2002)^{43}$ — concerns the safety liabilities, responsibilities, and requirements for the space vehicles intended to be launched from French Guiana Space Center launch site (CSG), with nuclear sources on board provided by a foreign country.

${ }^{37}$ Council Decision 87/600/Euratom of 14 December 1987 on Community arrangements for the early exchange of information in the event of a radiological emergency. Official Journal of the European Communities L 371, Vol. 30 (December 30, 1987). Available from: http://eur-lex.europa.eu/legalcontent/EN/TXT/?uri=uriserv:OJ.L_.1987.371.01.0076.01.ENG\&toc=OJ:L:1987:371:TOC [Accessed 10th March 2017].

${ }^{38}$ Rules Concerning Space Activities and the Establishment of a Registry of Space Objects, Bill (June 06, 2006). Available from: http://www.unoosa.org/oosa/en/ourwork/spacelaw/nationalspacelaw/netherlands/ space_activities_actE.html [Accessed 10th March 2017].

${ }^{39}$ Regulation of the Federal Minister for Transport, Innovation and Technology in Implementation of the Federal Law on the Authorisation of Space Activities and the Establishment of a National Space Registry. BGBl. II No. 36/2015 Available from: http://www.unoosa.org/documents/pdf/spacelaw/national/austria/ Austrian_Outer_Space_Regulation_German_original_BGBLA_2015_II_36E-unofficial-translation.pdf [Accessed 10th March 2017].

${ }^{40}$ Law of 17 September 2005 on the Activities of Launching, Flight Operations or Guidance of Space Objects, consolidated text as revised by the Law of 1 December 2013. Moniteur Belge of January 15, 2014. Available from: https:/www.belspo.be/belspo/space/doc/beLaw/Loi_en.pdf [Accessed 10th March 2017].

${ }^{41}$ European Code of Conduct for Space Debris Mitigation, Issue 1.0, (June 28, 2004). Available from: http://www.unoosa.org/documents/pdf/spacelaw/sd/2004-B5-10.pdf [Accessed 10th March 2017]. At p. 2. ${ }^{42}$ Ibid.

43 Nuclear Safety Requirements. RNC-CNES-R-15 Version 1 (July 17, 2002). Available from: http://www.apc.univ-paris7.fr/APC/Labo/Espace_Qualite/tch/normes/CNES/RNC-CNES-R-15-E-A.pdf [Accessed 10th March 2017]. 
Some above-mentioned documents took into account NPS Principles' provisions and in some documents the requirements on the use of nuclear power sources essentially are more strictly and modern then in NPS Principles, and also is detailed, bearing in mind national interests. One must note that for the past 50 years, the EU, the European Space Agency (ESA) and the Member States have developed high level safety standards on the use of nuclear power sources in comparison with other space faring nations such as Russia and the USA. The abovementioned standards aim at protection of the individuals, society and environment (Aftergood, Hafemeister, Prilutskiy, Primack, Rodionov, 1991:42-47).

\section{CONCLUSION}

The overall analysis confirms that the NPS Principles are mostly implemented in the national legislation of States. However, it is obvious that NPS might bring a serious threat to the mankind in case of defective engineering or operation that would result in causing substantial damage to the environment. Thus, it is necessary to transform the NPS Principles into legally binding international rules for the States that carry out outer space activities with NPS.

Further, mention should be made that NPS Principles have turned out to be outdated. First, NPS Principles have a restrictive field of application with the lapse of time and progress in science and technology. Second, the Principle's reference framework for radiological protection has evolved.

Bearing in mind the above, the task of drafting a new relevant international treaty could be put on the world agenda. This is precisely why LST and STSC of UN COPUOS in cooperation with IAEA should review and improve NPS Principles and ensure greater consistency with the new Safety Framework (Dunk, 2015; Wolter, 2006) and states' practice such as the Russian Federation, the USA and the EU.

\section{REFERENCES} 93-107.

Aftergood, S. (1989) Background on Space Nuclear Power. Science \& Global Security. 1,

Aftergood, S., Hafemeister, D. W., Prilutskiy, O. F., Primack, J. R. \& Rodionov, S. N. (1991) Nuclear Power in space. Scientific American. 264 (6), 42-47.

Beard, J.M. (2016) Soft Law's Failure on the Horizon: The International Code of Conduct for Outer Space Activities. In: Space and Telecommunications Law Program Faculty Publications. Paper. 87. Available from: http://digitalcommons.unl.edu/spacelaw/87_[Accessed 18th May 2017]

Bennett, G. L. (1995) A Technical Review of the U.N. Principles on the Use of Nuclear Power Sources in Outer Space. Available from: https://fas.org/nuke/space/technical.pdf [Accessed 20th May 2017]

Bennett, G. L., Sholtis, J.A. \& Rashkow, B.C. (1989) United Nations Deliberations on the Use of Nuclear Power Sources in Space: 1978-1987. In: EI-Genk, M. S., Hoover, M. D. (eds.) Space Nuclear Power Systems 1988. Malabar, Florida, Orbit Book Company Inc, pp. 45-58.

Boczek, B. A. (2005) International Law: A Dictionary. Lanham, Scarecrow Press. 
Dunk, F. (2012) Contradictio in terminis or Realpolitik? A Qualified Plea for a Role of 'Soft Law' in the Context of Space Activities. In: Space and Telecommunications Law Program Faculty Publications. Paper 68. Available from: http://digitalcommons.unl.edu/spacelaw/68 [Accessed 18th May 2017]

Dunk, F. \& Tronchetti, F. (2015) Handbook of Space Law. Cheltenham, Edward Elgar Publishing Limited.

Durdenevskii V. N. \& Krylov, S. B. (1947) Mezhdunarodnoe pravo [International Law]. Moscow, Gosyurizdat.

Falk, R. A. (1967) New Approaches to the Study of International Law. American Journal of International Law. 61 (2), 477-495.

Kozhevnikov, F. I. (1957) Mezhdunarodnoe pravo [International Law]. Moscow, Gosyurizdat. (in Russian)

Lyall, F., Larsen, P. B. (eds.) (2009) Space law: a treatise. Aldershot, Ashgate Publishing Group.

Marboe, I. (2012) Soft law in outer space: the function of non-binding norms in international space law. Wien, Böhlau Verlag.

Mayence, J. F. (2011) Granting Access to Outer Space: Rights and Responsibilities for States and Their Citizens - An Alternative Approach to Article VI of the Outer Space Treaty, Notably through the Belgian Space Legislation. In: Dunk, F. (ed.) National Space Legislation in Europe. Leiden, Martinus Nijhoff Publishers, pp. 73-124.

Minasyan, N. M. (1966) Pravo mirnogo sosushchestvovaniya [The Law of Peaceful Coexistence]. Rostov-on-Don, Rostovskii universitet Publ. (in Russian)

Morozov, G. I. (1962) Organizatsiya Ob»edinennykh Natsii (Osnovnye mezhdunarodnopravovye aspekty struktury $i$ deyatel'nosti) [United Nations (The Basic International Legal Aspects of Structure and Activities)]. Moscow, IMO Publ. (in Russian)

Portalis, J. E. M. (1820) De l'usage et de l'abus de l'esprit philosophique durant le dixhuitième siècle. Tome 1. Paris: A. Egron, Imprimeur.

Rozman R. (2012) Nuclear Energy in Space. Available from: http://mafija.fmf.unilj.si/seminar/files/2011_2012/NUCLEAR_ENERGY_IN_SPACE_ROK_ROZMAN.pdf [Accessed 20th January 2017].

Schwelb, E. (1966) Neue Etappen der Vortentwicklung des Völkerrechts durch die Vereinten Nationen. Archiv des Völkerrechts. 13 (1), 1-52.

Summerer, L., Gardini, B. \& Gianfiglio, G. (2007) ESA's Approach to Nuclear Power Sources for Space Applications. In: Proceedings of ICAPP. 13-18 May, Nice, France. Available from: http://www.esa.int/gsp/ACT/doc/POW/ACT-RPR-NRG-2007-SummererGardiniGiacintoICAPP-ESAs-Approach-to-NPS-for-Space-Applications.pdf [Accessed 18th May 2017].

Tunkin, G. I. (2014) Teoriya mezhdunarodnogo prava [Theory of International Law]. Moscow, IKD «Zertsalo-M». (in Russian)

Verdross, A. (1955) Völkerrecht. Dritte neubearbeitete und erweiterte Auflage. Translated from German Kublitskii, F. A., Naryshkina, R. L. (1959) Moscow, Inostrannaya literatura Publ.

Vereshchetin, V. S. (2010) The Law of Outer Space in the General Legal Field (Commonality and Particularities). In: Jorgenson, C. M. (ed.) Proceedings of the International Institute of Space Law. Washington, D.C., AIAA. pp. 3-14.

Wolter, D. (2006) Common Security in Outer Space and International Law. Geneva, Switzerland, United Nations Institute for Disarmament Research.

Zhukov, G. P., Abashidze, A. Kh. (eds.) (2014) Mezhdunarodnoe kosmicheskoe pravo [International Space Law]. Moscow, RUDN Publ. (in Russian) 


\title{
INFORMATION ABOUT THE AUTHOR
}

Chernykh Irina A. - Post-graduate Student, Department of International Law, Law Institute, RUDN University.

Contact information:

e-mail: i.chernykh.law26@gmail.com

For citation:

Chernykh, I. A. (2017) Soft Law Realisation in the Context of "Principles Relevant to the Use of Nuclear Power Sources in Outer Space": Case Study the Russian Federation, the United States of America and the European Union States. Vestnik Rossiiskogo universiteta druzhby narodov. Seriya: Yuridicheskie nauki [RUDN Journal of Law]. 21 (3), pp. 436-450. Available from: doi:10.22363/2313-2337-2017-21-3-436-450.

\section{РЕАЛИЗАЦИЯ МЯГКОГО ПРАВА В КОНТЕКСТЕ «ПРИНЦИПОВ, КАСАЮЩИХСЯ ИСПОЛЬЗОВАНИЯ ЯДЕРНЫХ ИСТОЧНИКОВ ЭНЕРГИИ В КОСМИЧЕСКОМ ПРОСТРАНСТВЕ»: ПРАКТИКА РОССИЙСКОЙ ФЕДЕРАЦИИ, США И ГОСУДАРСТВ ЕВРОПЕЙСКОГО СОЮЗА}

\author{
И.А. Черных \\ Российский университет дружбы народов \\ Юридический институт \\ 117198, Москва, Россия, ул. Миклухо-Маклая, 6
}

\begin{abstract}
В настоящее время в международном публичном праве одной из наиболее дискуссионных проблем является роль и место «мягкого права». Некоторые ученые считают, что можно говорить о такой отрасли, как «мягкое право», другие придерживаются мнения, что «мягкое право» является источником международного публичного права. При этом приверженцы различных подходов сходятся во мнении, что акты, содержащие нормы «мягкого права», обладают такими чертами, как необязательный характер и быстрый процесс принятия таких документов.

Таким образом, государства-участники международных межправительственных организаций, учитывая вышеуказанные характеристики «мягкого права», используют его как способ преодоления разногласий между государствами в случае неудачи в принятии универсального международного договора. В статье подтверждается существование подобной практики в международном космическом праве. В частности, с момента вступления в силу Соглашения о Луне 1979 г. государства-члены Комитета ООН по использованию космического пространства в мирных целях до сих пор не приняли ни одного нового международного договора по космосу. Однако они нашли решение в сложившейся ситуации: разрабатывать и принимать документы «мягкого права», например, резолюции Генеральной Ассамблеи ООН и иные относящиеся к «мягкому праву» документы.

При том что резолюции Генеральной Ассамблеи не носят обязательный для исполнения характер, государства могут трансформировать их в национальное законодательство и таким образом регулировать на национальном уровне еще не урегулированные в международном праве вопросы, связанные с осуществлением космической деятельности.
\end{abstract}


Черных И.А. Вестник РУДН. Серия: Юридические науки. 2017. Т. 21. № 3. 436-450

Целью данной работы является как рассмотрение становления «мягкого права» как потенциально нового источника международного космического права, так и проведение сравнения и анализа практики государств по трансформации документов мягкого права в национальное законодательство таких государств, как Российская Федерация, США и некоторых государствчленов Европейского Союза. В качестве рассматриваемого документа мягкого права будет взята резолюция Генеральной Ассамблеи ООН от 1992 г., утверждающая «Принципы, касающиеся использования ядерных источников энергии в космическом пространстве» (Принципы ЯИЭ), так как вопросы по использованию ядерных источников энергии в космическом пространстве должны регулироваться с учетом тщательной оценки безопасности.

Настоящая статья начинается с краткого обзора концепции «мягкого права» и резолюций, подготовленных Генеральной Ассамблеей ООН. Далее статья включает в себя три части и заключение. Первая часть включает краткую историческую справку о подготовке Принципов ЯИЭ, вторая часть - рассмотрение работы Комитета ООН по использованию космического пространства в мирных целях и Международного агентства по атомной энергии по вопросам, связанным с использованием ядерных источников энергии в космическом пространстве. Заключительная часть содержит анализ практики государств по трансформации положений Принципов ЯИЭ в национальную правовую систему, включая дополнительные инструменты регулирования использования ядерных источников энергии, анализ особенностей и различий в выбранных для проведения исследования государствах.

Ключевые слова: принципы, касающиеся использования ядерных источников энергии в космическом пространстве; мягкое право; космическое право; Комитет ООН по использованию космического пространства в мирных целях; МАГАТЭ; национальное законодательство; рамки обеспечения безопасного использования ядерных источников энергии в космическом пространстве; безопасность; резолюции Генеральной Ассамблеи ООН

\section{СВЕДЕНИЯ ОБ АВТОРЕ}

Черных Ирина Алексеевна - аспирант кафедры международного права Юридического института Российского университета дружбы народов.

Контактная информация:

e-mail: i.chernykh.law26@gmail.com

\section{Для цитирования:}

Chernykh I.A. Soft Law Realisation in the Context of "Principles Relevant to the Use of Nuclear Power Sources in Outer Space": Case Study the Russian Federation, the United States of America and the European Union States // Вестник Российского университета дружбы народов. Серия: Юридические науки. 2017. Т. 21. № 3. С. 436-450, doi:10.22363/2313-2337-2017-21-3-436-450. 